\title{
WWF's Green Business Model in Protected Area Conservation and Livelihoods Sustenance in Cameroon: The Need for a Shift in Approach?
}

\author{
Jude Ndzifon Kimengsi ${ }^{1,2}$, Jürgen Pretzsch ${ }^{1}$, Eckhard Auch ${ }^{1} \&$ Balgah Roland Azibo ${ }^{3}$ \\ ${ }^{1}$ Institute for Tropical Forestry and Forest Products, Technische Universität Dresden, 01737 Tharandt, Germany \\ ${ }^{2}$ Department of Geography and Environmental Studies, Catholic University of Cameroon, Cameroon \\ ${ }^{3}$ College of Technology, University of Bamenda, Cameroon \\ Correspondence: Jude Ndzifon Kimengsi, Institute for Tropical Forestry and Forest Products, Technische \\ Universität Dresden, 01737 Tharandt, Germany.E-mail: jude_ndzifon.kimengsi@tu-dresden.de
}

Received: February 20, 2018

Accepted: October 19, 2018

Online Published: January 4, 2019

doi:10.5539/enrr.v9n1p9

URL: https://doi.org/10.5539/enrr.v9n1p9

\begin{abstract}
Rising interests to support green development through targeted conservation approaches in the developing world attracted international NGO attention especially in the 1990s. One of such NGOs, the World-Wide Fund for Nature (WWF) has been backstopping many African nations in the process of realizing the twin objectives of livelihood sustenance and protected area conservation. In the case of Cameroon, one of her key areas of intervention has been the introduction of green business initiatives as a way of strengthening the link between livelihood support and conservation in protected areas. With a focus on Cameroon, we review the green business model (Note 1) as a WWF intervention approach in Africa. We undertake a random survey of household representatives drawn from $7 \mathrm{WWF}$ conservation cooperatives in Cameroon on their perceptions and preferences with regards to the green business initiative. This was complemented by interviews to $8 \mathrm{WWF}$ and partner CSO representatives, and field observations. The results are discussed to include a schema of the green business approach in Africa with a focus on Cameroon, cooperative members' knowledge levels of the initiative, impact of the initiative and clarity of benefit sharing schemes in place, among others. The pairwise correlation shows a strong positive relationship between knowledge/experience levels and a number of elements including shortcomings of the initiative, the need for strategy improvement, and the tendency for outside influence on the green business choices. This aspect equally showed a strong positive correlation with the need to switch to other green business options and unclear benefit sharing. In conclusion, we argue for a shift in the green business approach to capture issues of improvement in knowledge levels, diversification, technical and institutional capacity building, clarity of benefit sharing, and value chain development. We further advocate for a green business approach in tandem with the aspirations of local populations around protected areas on the one hand, and the need for a conservation cooperative alliance on the other hand. The results contribute to the "green economy" discourse which has significantly gained grounds in all spheres of conservation and development interventions.
\end{abstract}

Keywords: WWF, green business, conservation, livelihoods, Africa

\section{Introduction}

More than one billion people live around forests, relying on them for livelihoods sustenance (Muller \& Johnson, 2009). A majority of these people are poor who almost invariably, grapple with ill-conceived and ill-prepared conservation interventions which largely fail to make provisions for alternative survival strategies (Muller \& Johnson, 2009). Global concerns on the ethical and economic impacts of protected areas have generated interest in participatory conservation initiatives for local inhabitants (Mustalahti \& Nathan, 2009; Mustalahti \& Lund, 2010; Kimengsi \& Balgah, 2016). This has been reinforced by the sustainable development theory which explains the compatibility between economic development and natural resource conservation. The propagation of the sustainable development philosophy catalyzed the multiplication of conservation sites especially in the developing world; these spaces represented key areas of biodiversity protection that can simultaneously support the rural economy (Adams, 2001; King, 2007; Buchenrieder \& Balgah, 2013). The conservation sites approach has 
generally produced more negative than positive results across Africa (see for instance Njiforti \& Tchamba, 1993; Neumann, 1997; Newmark, 2008; Lambi et al., 2012).

As a counter measure to the growing decline in global environmental health, models on the "green economy" have significantly gained grounds in all spheres of conservation and development interventions (AfDB/WWF, 2012; UNEP, 2014). This model resonates from the premise that natural resource sustainability can be mainstreamed in economic growth (AfDB/WWF, 2012). This has encouraged governments, economic operators and the civil society to undertake moves to actualize the green economy initiative. One of such relates to the green business initiative which is applied (albeit in diverse proportions) in biodiversity conservation and livelihood sustenance by organizations such as the International Union for the Conservation of Nature (IUCN), Deutsche Gesellschaft für Internationale Zusammenarbeit (GIZ) GIZ and WWF. The green business initiative is an extraction from concepts such as "green growth" and green economy; discussions on the transition to a green economy stresses on the role of forests in the context of natural capital (e.g. OECD, 2011; World Bank, 2012).

The process of promoting livelihood activities that, at best, promote environmental and social development and leave minimal harm to the environment or human welfare is viewed as green growth. 'Green growth' encompasses job creation or economic growth that is either compatible with, or driven by reduced emissions, improved efficiencies in the use of natural resources, and protection of ecosystems (World Bank 2012; UNEP 2011; Sperling et al., 2012). A refined understanding of the green growth concept is provided by the United Nations Conference on Sustainable Development $(\mathrm{Rio}+20)$ as a process which contributes to eradicate poverty as well as to achieve sustained economic growth, enhance social inclusion, improve human welfare and creating opportunities for employment and decent work for all, while maintaining the health of the earth's ecosystems (UNCSD, 2012). Achieving green growth and promoting a green economy in Africa requires the pursuance of inclusive economic growth through policies and initiatives that invest in sustainable infrastructure, better manage natural resources, build resilience to natural disasters, and enhance food security (Sperling et al., 2012). This is emphasized in Agenda 2063, Africa's 50years development blueprint, which provides an enabling framework for environmental sustainability (AUC, 2015). In a green economy, livelihoods sustenance should be driven by investments that reduce carbon emissions and pollution, enhance energy and resource efficiency, and prevent biodiversity loss (UNEP, 2011).

The rising interest to support the green development process of developing nations especially from a conservation perspective, led to the streaming of international conservation NGOs. This trend witnessed a dramatic surge in the 1990s, as a rainbow of national and international NGOs became active within the African conservation landscape (Bratton, 1994; Charnovitz, 1997; Breitmeier \& Volker, 2000). In spite of varying visions and statements of intent, these NGOs generally converged on the need to collective save biodiversity. International NGOs channeled funds through local NGOs and community groups in a bid to positively influence the conservation process. NGO funding therefore played an important role in the conservation of protected areas (Cooka et al., 2017). Consequently, both local and international NGOs gained recognition as important sources of funding and actors for nature conservation in developing nations. The fact that most conservation related funding is channeled through NGOs bears eloquent testimony to this assertion (Mercer, 2002; Gibson et al., 2005). While it is agreed that external NGO funding might facilitate environmental governance, there is also evidence to suggest that NGO funding might undermine local interests in natural resource governance. This is largely possible, especially in cases where recipient communities have low financial capacities (Wright \& Andersson, 2012). Informational asymmetry and the conditional nature of external NGO funding for conservation may explain in part why some externally funded projects are poorly suited to local contexts (Ostrom et al., 1993; Gibson et al., 2005; Wright \& Andersson, 2012; Andersson, 2013).

Cameroon was not left out of this dynamic. As the $8^{\text {th }}$ most forested country in the world, it counts over 30 protected areas including wildlife sanctuaries, national parks and forest reserves which span across the country (CBFP, 2005; Tchindjang \& Fogwe, 2009). These protected areas have come under serious pressure over time, due to the extensive logging process on the one hand, and the incessant distortion of the forest for agriculture and the search for non-timber forest products (NTFPs) on the other hand. In recognition of this predicament, the state established a legal framework, created enabling institutions (Note 2), and encouraged public-private partnerships for biodiversity conservation (Lambi et al., 2012). These actions attracted numerous conservation NGOs including the Wildlife Conservation Society (WCS), GIZ, Birdlife International and WWF.

Despite the increase support to government efforts from such NGOs, it remains debatable on the extent to which NGO intervention through funding and green enterprises have been successful in achieving biodiversity conservation and livelihoods improvement. The entry point in this on-going debate revolves around the WWF green business initiative in conservation and livelihood support. WWF, one of the leading conservation NGOs in 
Cameroon has, in the recent past introduced a "green business model" in her strive towards livelihoods support and biodiversity conservation. The emphasis of this initiative is on support provision for conservation cooperatives to engage in activities that are compatible with conservation. In this paper, we discuss the green business initiative in Africa with a focus on Cameroon, analyse household representatives knowledge levels of the initiative, impact of the initiative and clarity of benefit sharing schemes in place, among others. We argue for a shift in the green business approach to capture issues of improvement in knowledge levels, diversification, technical and institutional capacity building, clarity of benefit sharing, and value chain development, among others.

This paper will proceed as follows: The next section (Section Two) provides a discourse on the conservation-livelihood nexus which represents a key anchor for the study. Here we discuss the link between conservation and livelihoods as espoused by different authors and further analyse the evolving paradigms in the field of conservation. The section wraps up with the sustainable livelihoods approach. In section three, we describe the methodology which essentially involves a sample of household members whose views were used to support the field experiences gained during consultancy assignments for WWF. Section four discusses the framework of the WWF green business initiative and analyses cooperative members' perceptions of the initiative. This opens up discussions for section five which argues on the need for a shift in approach and draws conclusions.

\section{The Conservation-Livelihood Sustenance Nexus}

Scientific research has over the years, proven that the poor in rural communities largely depend on natural resources for their survival (Scoones 1998; De Haan, 2000; Dalal-Clayton et al., 2003; Pretzsch, 2005; Kimengsi \& Balgah, 2017). Therefore, analyzing the link between conservation and livelihoods is primordial especially for these groups of people. It is fair to note that from inception, conservation and livelihoods represent two opposing positions, especially when one recognizes the fact that many conservation programmes were meant to protect and by implication, deprive marginal communities of their livelihood assets (Blaikie \& Jeanrenaud, 1997; Salafsky \& Wollenberg, 2000). A contrary school of thought however suggests that since resources are crucial to sustain livelihoods, it is primordial to conserve these resources, if sustaining livelihoods is an implicit or explicit objective (Berkes 2004b; Folke et al., 2005). These divergent approaches in the field of conservation and sustainable livelihoods have resolved into at least three observed paradigms in the topical literature. These include the classical, the neo-liberal and the neo-populist approaches.

The classical approach was characterized by the absence of a livelihoods-conservation linkage (Njiforti \& Tchamba, 1993; Blaikie \& Jeanrenaud, 1997). A significant aspect of this "biocentric approach" has been the move towards the creation of parks and protected areas that exclude livelihood activities (McNeeley \& Miller, 1984; Western \& Wright, 1994; Salafsky \& Wollenberg, 2000; Lambi et al., 2012). The neo-liberal approach is considered to be controversial as it is based on the idea that institutions, policies, and markets act as economic incentives for sustainable biodiversity conservation by the local population (Brown 2002; Shukla 2004). The idea in this approach is that local stakeholders benefit from incentives which presumably stops them from posing threats to biodiversity; livelihoods is seen in this case to drive conservation, rather than simply being compatible with it (Salafsky \& Wollenberg, 2000). Conservation is therefore increasingly viewed as a social and political process, and as the incorporation of the nature-society interactions (Brown 2002; Berkes 2004b). This notion makes it difficult for people to distinguish between ecological and social systems since people are now viewed as an integral part of nature (Brown 2003b; Berkes et al., 2003; Berkes 2004b; Folke et al., 2005). The neo-populist approach views capacity building and the participation of local people as key elements to sustainable conservation and development. This "people centred" approach signaled the promotion of livelihood sustaining economic opportunities that are feasible around parks and protected areas. It supports the resource rights of local people and the need to sustain their livelihoods (Wells \& Brandon, 1992; Salafsky \& Wollenberg, 2000; Shukla 2004). The approach fits into the WWF green business approach which seeks to promote livelihood sustaining activities (green business initiatives) around protected areas with a view to effectively integrate and sustain livelihoods assets (forests, parks and wildlife sanctuaries in this case) as espoused in the sustainable livelihoods framework. The sustainable livelihoods framework which was championed by the Department for International Development (DFID) has gained grounds as a useful tool in livelihoods analysis especially for poor, vulnerable and marginalized communities (DFID 1999). In this case it is conceived as the livelihood sustenance activities undertaken by the poor communities around natural sites (protected areas) in their quest for survival (Adato \& Meinzen-Dick 2002). Singh (1996) considers it as a means of life for individuals and communities. In the context of conservation, livelihoods represent the activities undertaken by the adjacent population within or around protected areas as they strive to eke out a living. To Chambers and Conway (1992), a livelihood is sustainable when it can adjust and recover from stresses and shocks without significantly affecting the livelihood assets (Scoones, 1998). This concept relates to the conditions of wellbeing, capabilities, resilience and natural resource base of individuals and 
communities (De Haan, 2000). Five potential outcomes are identified in the livelihoods approach to include increased income, increased well-being, reduced vulnerability, improved food security and more sustainable use of the natural resource base (Chambers \& Conway, 1992). The discussion on knowledge levels, impact and benefit sharing situation for conservation cooperatives have a bearing on livelihoods outcomes, especially on income and well-being. Although the discussion is not directly mirrored on the sustainable livelihoods approach, it is evident that support to current and future livelihoods for the majority of the poor masses, will rest in part, on the shift in the green business approach.

\section{Methodology}

In this study, we undertake a concise review of literature on the green economy and green enterprise initiative and briefly discuss cases from some countries in Africa such as Kenya, Tanzania and Uganda. The review focuses on the typology, experiences and future perspectives of green business initiatives in conservation. This gives room for the discussion to be narrowed to WWF intervention in Cameroon as an empirical case study. Our focus in this study is on the WWF Coastal Forests Programme (WWF-CFP) - the largest intervention area in Cameroon (Figure 1). The programme covers much of the South West and Littoral Regions of Cameroon and focuses on the creation and empowerment of conservation cooperatives. A total of 7 conservation cooperatives are found around the Bakossi National Park covering over 760 members who are household representatives. From this target group, a $7 \%$ sample (56) of household representatives drawn from 7 conservation cooperatives were randomly sampled based on their perceptions and preferences with regards to the initiative. The five point likert scale (Note 3) (strongly agree, agree, neutral, disagree, strongly disagree) was used in this respect to samples respondents perceptions of the green business initiative and their future preferences. This was complemented by interviews to 8 WWF and partner CSO representatives to shed light on their perspectives about the initiative.

The Coastal Forests Programme plays hosts to key biodiversity hotspots such as the Bakossi National Park and the Bayang Mbo Wildlife Sanctuary where 7 conservation cooperatives engaged in the green enterprise initiative are located (Table 1). In addition, field experiences gained as green business planning consultants, conservation cooperative facilitators, and as monitoring officers on green business projects for WWF and her partner Civil Society organizations in a number of protected area communities in Cameroon between 2012 and 2017 have been employed to enrich the paper.

Table 1. Survey of respondents in the study area

\begin{tabular}{lcc}
\hline \multicolumn{1}{c}{ Cooperative } & Head quarters & No. Sampled \\
\hline Societe de cooperatives des eleveurs pour la protection de l'environement et du & & 8 \\
developpement durable du Litoral (SOCO.EPDDL) & Nkongsamba & 8 \\
ALIN KUPE Cooperative Union & Nyasoso & 8 \\
Bangem Area Conservation Cooperative (BACCOOP) & Bangem & 8 \\
Nninong Farmers Cooperative Union (NFCU) & Muaku & 8 \\
Tombel Conservation and Development Cooperative (TOCODEC) & Tombel & 8 \\
Western Bakossi Livestock and Environmental Preservation Cooperative (WEBALEPCO) & Mekom & 8 \\
Bakossi Non-Timber Forest Product Cooperative Society (BANOTIFOP-COOP) & Bangem & \\
\hline
\end{tabular}

During such consultancy exercises, the authors employed participatory rural appraisal (PRA) tools such as focused group discussions and interviews with 8 key informants comprising local group leaders, cooperative members and other forest stakeholders. The results are discussed to include a schema of the green business approach in Africa with a focus on Cameroon, a descriptive analysis of the likert scale survey with respect to cooperative members' knowledge levels of the initiative, impact of the initiative and clarity of benefit sharing schemes in place, among others. This method was chosen to give an unbiased picture of respondents' viewpoints with a view to suggesting possibilities for a paradigm shift for greater conservation outcomes, based on lessons and experiences from other contexts. 


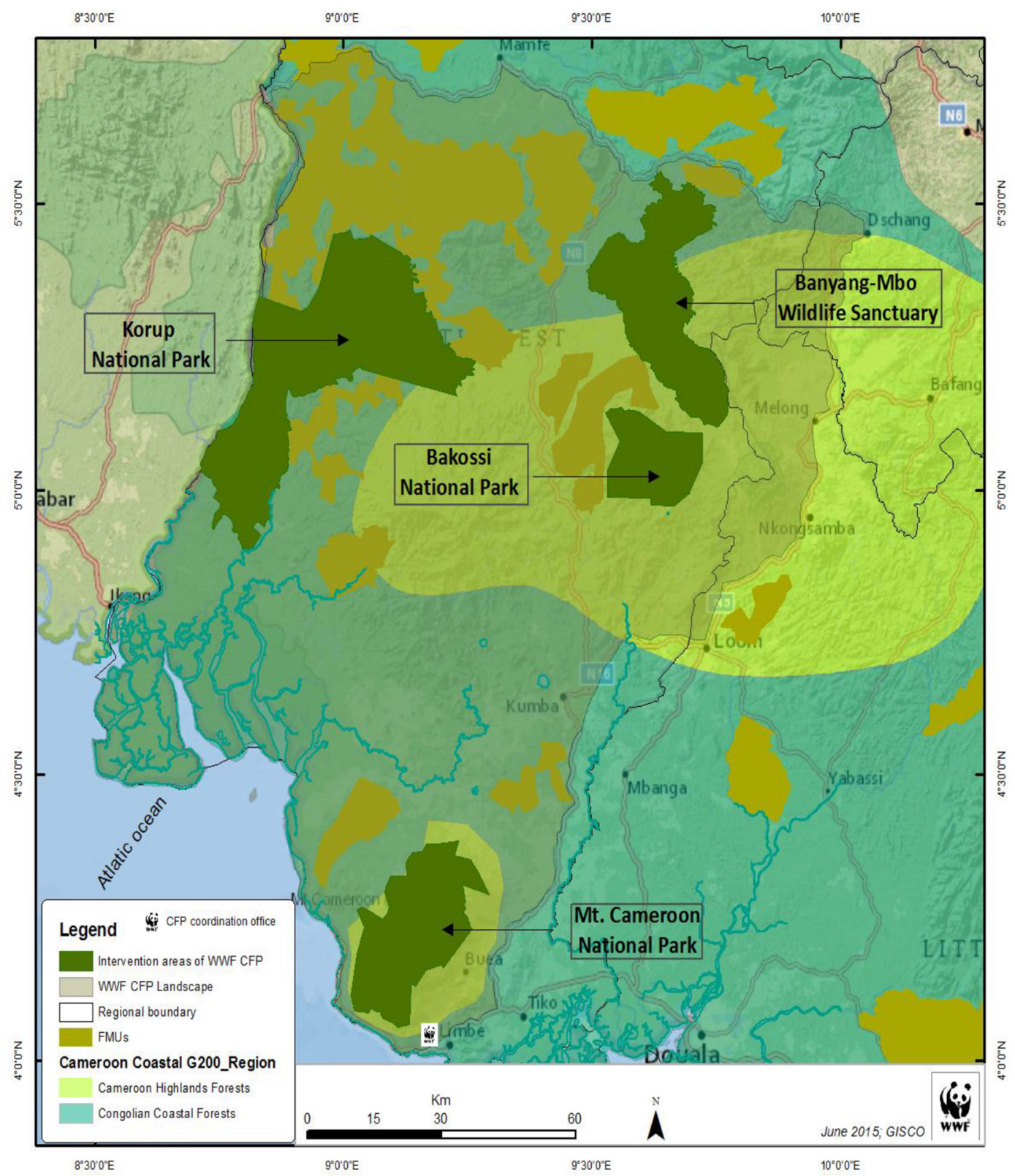

Figure 1: WWF Coastal Forests Programme intervention sites (WWF SAWA Updates, 2016)

\section{Results}

\subsection{The WWF Green Business Model}

The green business initiative is not new in the WWF global conservation intervention. This initiative had been applied in a number of African countries such as Kenya, Madagascar, Uganda and Tanzania. For instance, in Uganda, the initiative promoted local activities such as the harnessing of medicinal plants, weaving materials, bee farming and ecotourism. These initiatives were backed up by effective capacity strengthening of local groups to plan, negotiate and implement a wide range of activities, and the provision of support infrastructure and income diversification sources (WWF, 2017). A similar strategy was employed for Namibia where communal conservancies (covering 220,000 community members) have become a recognized conservation success story. Here, more than 80 communal conservancies engage in green business initiatives and generate more than $\$ 5$ million in annual income for the communities through diversified green business initiatives (Springer, 2013; WWF, 2017). WWF therefore drew inspiration from the earlier successful experiences to undertake the initiative in Cameroon. The model is designed to introduce initiatives that seek to curb poverty around protected areas through the sustainable management of natural resources. This involves enhancing the capacity of rural 
communities to manage and benefit from natural resources like beekeeping, pig farming, poultry farming, and sustainable agriculture. The initiative cycle begins with funding from the Swedish Development Agency (SIDA) to WWF Cameroon (Figure 2). WWF then initiates a process to regroup over 80CBOs into 7 conservation cooperatives and to propose the green business initiative to these groups. To facilitate the implementation of the initiative, WWF identifies and partners with relevant civil society organizations (CSOs) which will directly oversee the implementation of these initiatives, taking into consideration the fact that conservation cooperatives lack the technical and institutional capacity to do so. Initial start-up support is provided by WWF through the CSOs for the initiative to be implemented. This is followed by periodic feedback from the CSOs to WWF and then to SIDA. The above explanation presents a fairly smooth process which is far from the reality especially in terms of implementation at the local level.

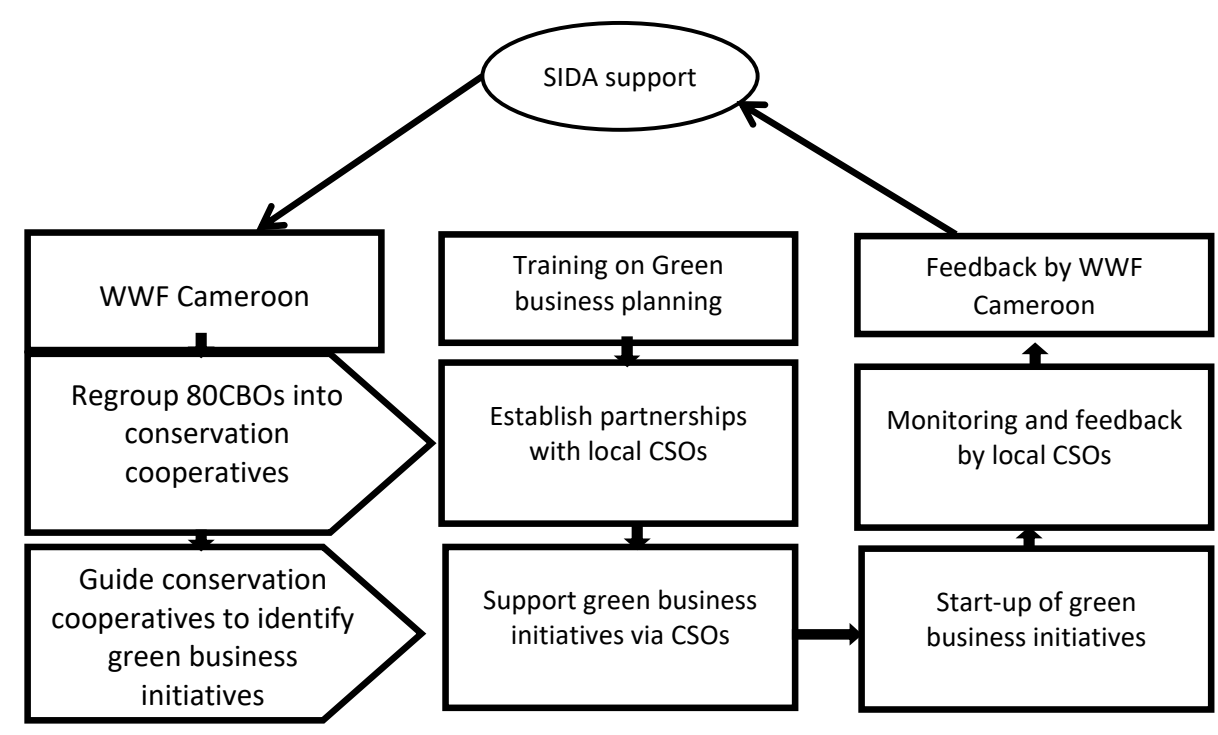

Figure 2. Schematic presentation of the WWF Green Business Initiative in Cameroon

Source: Authors' conception

\subsection{Demographic characteristics of respondents}

A total of 56 respondents drawn from 7 conservation cooperatives in the study area were randomly sampled. More than $60 \%$ of the sampled population fell between the age range of 18 and 40 , indicating that there are opportunities for continuity in the initiative. The gender representation however disfavoured the female folk (Figure 3).

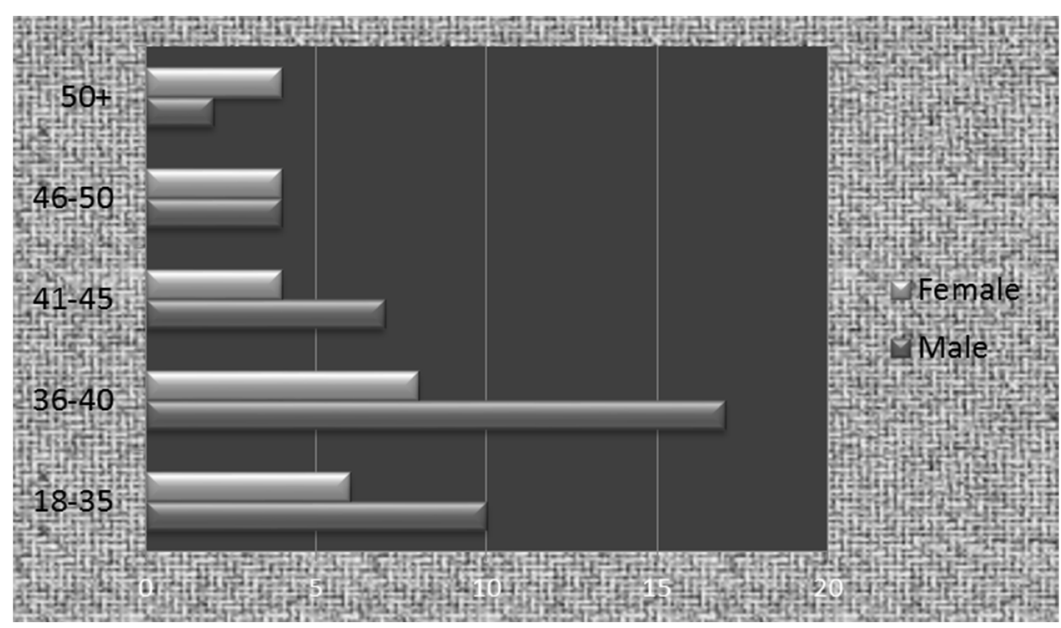

Figure 3. Demographic characteristics of Household representatives 


\subsection{Knowledge levels of the green business initiative}

More than $50 \%$ of the respondents indicated a poor knowledge of the initiative (Figure 4). They attest to the fact that some of their members were opportunied to attend a series of training workshops but could not adequately follow-up with the demands of the initiative.

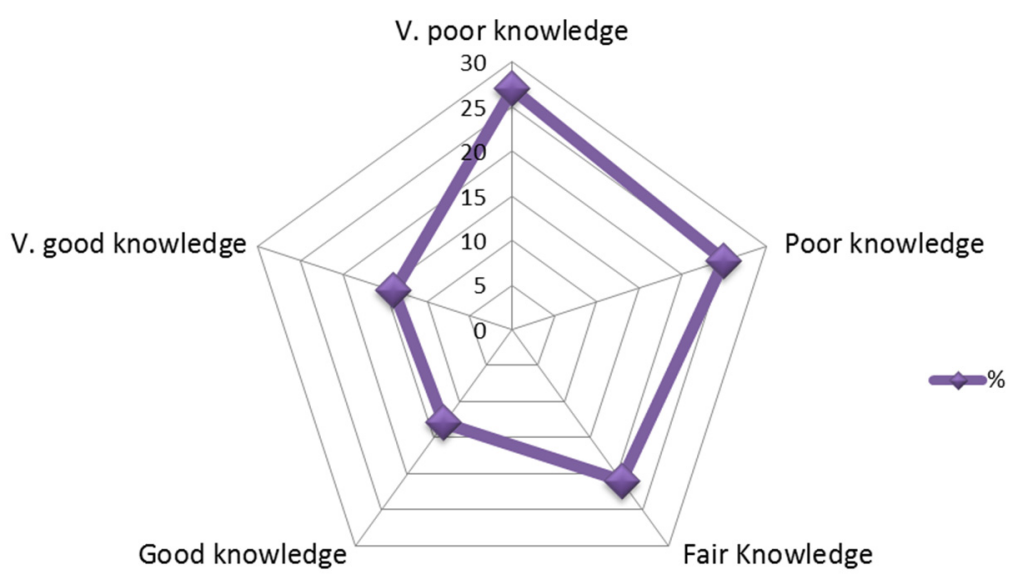

Figure 4. Household Knowledge levels of the green business Initiative

This made it difficult for such representatives to effectively transfer the knowledge gained to community members at large. In the case of Tanzania, Sesabo et al (2006) observed that compliance in resources management is constrained by limited knowledge levels. Knowledge levels were considered primordial in influencing local attitude towards compliance of conservation initiatives. Knowledge levels were equally determined by social networks in terms of group and/or association activities since households are able to benefit from knowledge improvement through information sharing. The importance of social networks in knowledge sharing on conservation initiatives have been emphasized in different contexts (Fiallo and Jacobson, 1995; Kellert 1996; Sesabo et al 2006). Social networking through cooperative groupings is evident in the study sites, although knowledge levels on the green enterprise initiative remain significantly low. Perhaps, the views espoused by Kellert (1996) that environmental education is relevant in affecting positive environmental attitudes among households could be evoked in this regard.

A significant proportion of the respondents noted that they felt some influence in the choice of their green business activities and would prefer to swicth to other activities, if given the opportunity (Table 2). They equally hold that their technical and institutional capacity limits constrains the effectiveness of the initiative.

Table 2. Likert scale results on some aspects of the Green business initiative

\begin{tabular}{|c|c|c|c|c|c|c|}
\hline Aspects & $\begin{array}{l}\text { SA } \\
(\%) \\
\end{array}$ & $\begin{array}{c}\text { A } \\
(\%) \\
\end{array}$ & $\begin{array}{c}\mathrm{N} \\
(\%) \\
\end{array}$ & $\begin{array}{c}\mathrm{D} \\
(\%) \\
\end{array}$ & $\begin{array}{l}\text { SD } \\
(\%)\end{array}$ & $\%$ \\
\hline Green business choices were influenced & 25 & 29 & 18 & 16 & 12 & 100 \\
\hline Prefer to switch to other activities & 29 & 23 & 21 & 16 & 11 & 100 \\
\hline Cooperative capacity is limited & 29 & 25 & 21 & 16 & 9 & 100 \\
\hline Capacity building efforts are needed & 29 & 27 & 13 & 20 & 11 & 100 \\
\hline Product value chain is weak & 39 & 29 & 14 & 11 & 7 & 100 \\
\hline
\end{tabular}

Notes: $\mathrm{SA}=$ Strongly agree $\mathrm{A}=\mathrm{Agree}, \mathrm{N}=$ neutral, $\mathrm{D}=$ disgaree, $\mathrm{SD}=$ strongy disagree

This explains why a significant proportion (50\%) of the respondents agree that the impact of the green business initiative has been limited to a few households so far (Figure 5). Compliance to the initiative has been slowed by issues of weak value chain development and unclear benefit sharing, among others. The aspect of product value chain was equally echoed as most respondents (68\%) agree that product value chain development is still poorly developed. 


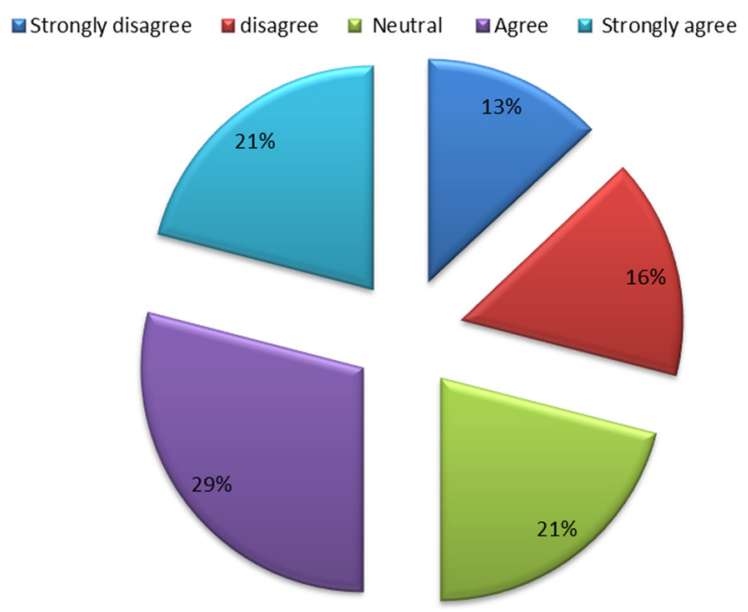

Figure 5. Household perception on the impact of the green business Initiative

The likert scale results indicate that $50 \%$ of the respondents agree that the initiative had a limited impact, involving just a few households as opposed to its expected great impact from inception. This could be attributed to the fact that some household members were not accustomed to particulare green enterprises and found it difficult to adhere to them. In some cases, household members were skeptical of the profitability of such initiatives. The scale of operation which was largely limited further constrained the expected wider impact to the target communities.

Table 3. Pairwise correlation of the WWF Green business initiative

\begin{tabular}{lcccc}
\hline & know level & Age & Sex & Experience level \\
\hline Shortcomings & $0.9062^{*}$ & $-0.9604^{*}$ & $-0.7353^{*}$ & $0.9346^{*}$ \\
strategy improvement & $0.9062^{*}$ & $-0.9604^{*}$ & $-0.7353^{*}$ & $0.9346^{*}$ \\
influenced choice & $0.9202^{*}$ & $-0.9622^{*}$ & $-0.7400^{*}$ & $0.9333^{*}$ \\
Need to switch & $0.9279^{*}$ & $-0.9729^{*}$ & $-0.7314^{*}$ & $0.9310^{*}$ \\
Ambitious targets & $0.9231^{*}$ & $-0.9525^{*}$ & $-0.7236^{*}$ & $0.9364^{*}$ \\
Limited project impact & $0.9303^{*}$ & $-0.9485^{*}$ & $-0.7332^{*}$ & $0.9370^{*}$ \\
Capacity building efforts needed & $0.9070^{*}$ & $-0.9684^{*}$ & $-0.7179^{*}$ & $0.9357^{*}$ \\
Weak value chain & $0.8333^{*}$ & $-0.9399^{*}$ & $-0.8249^{*}$ & $0.8821^{*}$ \\
Unclear benefit sharing & $0.8193^{*}$ & $-0.9072^{*}$ & $-0.7484^{*}$ & $0.8401^{*}$ \\
\hline
\end{tabular}

The pairwise correlation results (Table 3) show a strong positive relationship between respondents' knowledge and experience level and their position on the shortcomings of the green business initiative, the need for strategy improvement, and that their green business choices were influenced. On a similar note, knowledge and experience levels equally showed a strong positive correlation with proponents for the need to switch to other green business options and the fact that the benefit sharing scheme was unclear to many cooperative members. Age and sex was found to have a negative relationship with the identified project issues, implying that the negative issues raised were not dictated by age or sex levels.

\subsection{Clarity of benefits sharing schemes}

On the clarity of benefits sharing schemes, about $70 \%$ of the respondents noted that the benefit sharing scheme introduced and applied by their cooperatives remain unclear to most members (Figure 6). This justifies the low commitment level registered so far, as members remain skeptical of the initiative.

Benefit sharing, the arrangements where various benefits are distributed among stakeholders at all levels, is a widely used term in nature conservation (Peskett, 2011a; Campese, 2012). Benefit-sharing mechanisms can assume a vertical approach (across scales from national to local), and a horizontal approach including within and across communities, households and other local stakeholders (Lindhjem et al., 2010; UN-REDD, 2011; Pham et al., 2013). The latter is applicable in this case. Whatever form it takes, the design of benefit sharing schemes need to take into consideration a number of aspects to include target beneficiaries, the basis for which benefits are 
shared, clarity and forms and the adopted decision-making mechanisms. The sensitive nature of benefit sharing requires sufficient clarity which, if found to be nuanced, could breed mistrust and the lack of cooperation among cooperative members. This explains why there have been several calls for 'equity' and clarity in benefit sharing especially for the poor and marginalized groups (Hou, 2013; Torres \& Skutsch, 2014).

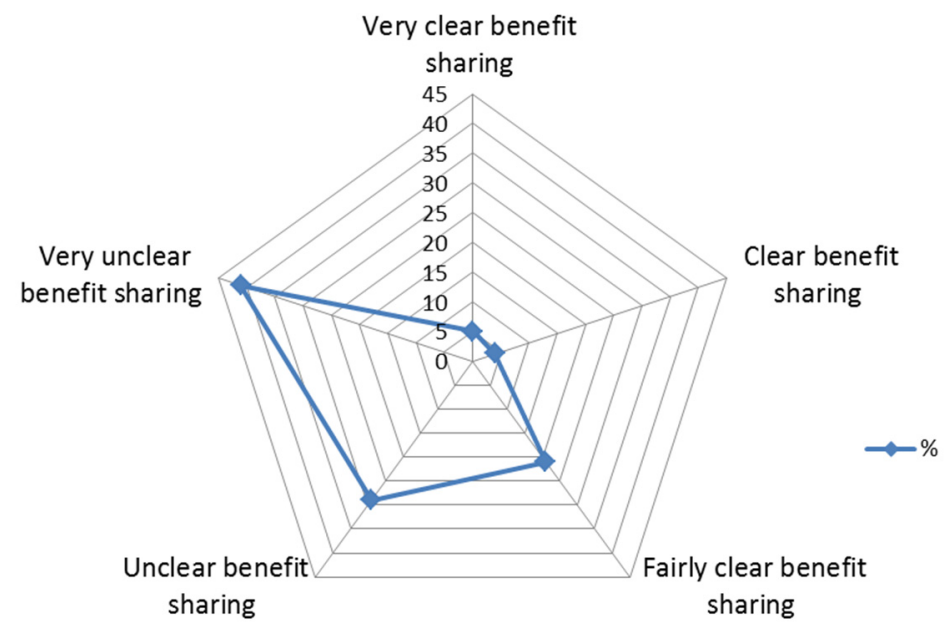

Figure 6. Respondents opinion on the clarity of benefit sharing schemes

Lack of commitment could equally be traced from the perception of cooperative members who had, over the years benefitted from direct cash flows from WWF to the CBOs with limited accountability. These members are yet to fully appreciate the new approach which engages them to efficiently use their start-up resources, engage in resource mobilization to improve their cooperative and adhere to accountability principles in their day-to-day green business affairs. The antecedent impact is still very much present in these communities. Local community members have defined WWF from the perspective of financial provisions for CBOs whose credibility at times remain questionable (cases where CBOs were created along family lines with the sole objective of reaping financial support from WWF). Green business community actors are yet to appreciate and move away from the statusquo ante of simply receiving funds over the years with limited accountability and conservation results. It corroborates Ostrom's views that external funding can, paradoxically, undercut local institutions' capabilities to sustain themselves over time due to their lack of self-reliance (Ostrom, 1995). This is seen from the spectrum of continued focus by local structures (in line with donors) to secure continued foreign funding rather than on improving collective income generation initiatives (Gibson, 1999; Rihoy \& Maguranyanga, 2010).

The nature conservation landscape has witnessed a shift in the approach employed by external organizations from lobbying (or working with) government wildlife institutions in host countries, to direct engagement with local stakeholders as well implementing their own projects and activities (Muchapondwa \& Stage, 2015). Although the green business initiative presupposes the provision of support for communities to engage in their respective income generating activities, such activities, in some cases have been tailored to largely meet the aspirations of WWF and her partners, rather than the real aspirations of local inhabitants. In some cases, capacity building efforts have been sporadic, short lived and limited in scope and impact. This leaves a few elitist community members to man the affairs of green business cooperatives to the disfavor of the majority. The below par level of participation implies a reduction in the negotiation capacity of communities for improved livelihood outcomes (Nelson \& Agrawal, 2008).

\section{Discussion and Conclusion}

The purpose of this paper was to analyse the WWF green business initiative in Africa, with focus on Cameroon. Emphasis in this study was on cooperative members' knowledge levels of the green business initiative, impact of the initiative and the clarity of benefit sharing schemes in place, among others. To achieve this, we undertake a concise review of literature on the green enterprise initiative and briefly discuss cases from some countries in Africa before narrowing it to WWF intervention in Cameroon. We employed the 5 point likert scale survey to randomly sample 56 household representatives drawn from 7 target conservation cooperatives in the WWF 
Coastal Forests Programme (WWF-CFP). We equally made us of field observations and the interviewing of 8 key WWF and partner CSO staff. The results have been analysed descriptively, beginning with a schema of the green business approach in Africa with a focus on Cameroon, a descriptive analysis of the likert scale survey with respect to cooperative members' knowledge levels of the initiative, impact of the initiative and clarity of benefit sharing schemes in place, among others. The pairwise correlation was employed to analyse the relationship between knowledge/experience and a number of elements including shortcomings of the initiative, the need for strategy improvement, and the tendency for outside influence on the green business choices.

One of the numerous hurdles that have slowed down conservation initiatives is the fact that organizations largely depend on external sources for funding and are therefore often unwilling to objectively report failures and shortcomings. This retards the process of improvement by learning (Jepson \& Canney, 2003; Gratwicke et al., 2007; Howe, 2009). In this paper, we argue that a clear identification of the shortcomings and the development of planning instruments to address them is a logical way forward towards improving biodiversity conservation and livelihoods.

The pairwise correlation shows a strong positive relationship between knowledge/experience levels and a number of elements including shortcomings of the initiative, the need for strategy improvement, and the tendency for outside influence on the green business choices. This aspect equally showed a strong positive correlation with the need to switch to other green business options and unclear benefit sharing. A logical starting point should be an improvement in the knowledge levels of the target communities on the green business initiative. WWF and partners should embark on a rigorous campaign to educate the communities on the new initiative especially as a significant number of the population still has the business-as-usual perception. As cooperatives have been created with their mandates to undertake green business, the shift in approach should consider the need to further activate technical and institutional capacity building in the model. Although some attempts have been made so far, empirical evidence suggests that the impact is not far reaching. Therefore, the augmentation of technical support in green business activities and organizational capacity building will further improve the activities of the cooperatives. Capacity building should go beyond the training of a few representatives to the organization of training-of-trainers programmes to ensure wider coverage of the programme. The crucial role of capacity building has been emphasized in the context of protected area conservation (Scherl \& O'Keeffe, 2016).

Capacity building will foster partnerships among cooperatives in a bid to improve their bargaining power and negotiate for product value chain improvement. The improvement of technical and institutional capacities should be complemented by rigorous lobbying for financial institutions to provide soft loans to these conservation cooperatives as part of their commitment to eco-friendly activities. This will support cooperative members to undertake large-scale green business ventures with significant benefits for members.

A majority of rural community members, including those adjacent to protected areas, have historically diversified their productive activities to involve a range of other productive areas, driven by multifarious motivations (Adams \& Mortimore, 1997; Dercon \& Krishnan, 1996; Ellis, 1996). At the moment, most of the cooperatives are operating along single green business lines. This represents a deviation from their initial green business plans which considered a range of activities, giving room for diversification (Table 3). The implication is that, since most of these products are natural resource and agriculture-linked, market fluctuations in these activities are likely to introduce unbearable shocks in the cooperatives (especially as product value chain development is absent). The need for diversification has been emphasized in conservation and development literature. Diversification has been observed in the context of Tanzania (Seppala, 1996; Ashley et al., 2002), Uganda (Bigsten \& Kayizzi-Mugerwa, 1995) and Kenya (Tiffen et al., 1994). Infact, in the case of Tanzania, it is viewed as a cultural and material strategy (Seppala. 1996).

Value chain analysis and improvement is imperative for the cooperatives in question. This process promotes enterprise development, lead to product quality enhancement and branding, ensures clarity in the quantitative addition along the chain, and promotes the coordination of linkages among producers, processors and retailers. It equally promotes efficiency and competition in green business initiatives (UNIDO, 2009). Value chain analysis and development represents an important tool for livelihoods improvement around forest reserve communities (Hoermann et al., 2010; Saini et al., 2016). The current weak value chain development can be improved rapidly through functional and process upgrading. This will, however, require a specific contextual analysis against the backdrop of poor accessibility, marginality, fragility, and diversity before the right value chain is selected. This calls for the designing of an adaptable value chain system for the conservation cooperatives. In the pursuit of value chain development, conservation cooperatives should apply caution not to end up on the losing end of the value chain. As Altenburg (2006) puts it, winners and losers are likely to emerge from value chains, and the net effects may not always be positive (Altenburg, 2006; UNIDO, 2009). As value chain improvement is meant to usher in 
significant benefits, a clear and effectively communicated benefit-sharing scheme is required to build trust and commitment among eco-cooperative members. These considerations should be fused into the on-going approach for improved outcomes.

Table 3. Planned and Actual green business activities for cooperatives

\begin{tabular}{|c|c|c|c|}
\hline Cooperative & Park Area & Planned Activities & Actual Activities \\
\hline SOCO.EPDDL & Bakossi National Park & $\begin{array}{l}\text { Poultry farming, pig farming } \\
\text { goat/sheep farming, bee keeping }\end{array}$ & Poultry Farming \\
\hline ALIN KUPE & Bakossi National Park & $\begin{array}{l}\text { Pig farming, poultry farming } \\
\text { goat/sheep farming, bee keeping }\end{array}$ & Pig Farming \\
\hline BACCOOP & Bakossi National Park & $\begin{array}{l}\text { Poultry farming, pig farming } \\
\text { goat/sheep farming, bee keeping, organic farming }\end{array}$ & Poultry Farming \\
\hline NFCU & Bakossi National Park & Pig farming & Pig Farming \\
\hline TOCODEC & Bakossi NP & $\begin{array}{l}\text { Bee keeping, pig farming, poultry farming, } \\
\text { goat/sheep keeping, organic farming }\end{array}$ & Bee Keeping \\
\hline WEBALEPCO & $\begin{array}{l}\text { Bakossi National Park \& Bayang } \\
\text { Mbo Wildlife Sanctuary }\end{array}$ & Pig farming, bee keeping & Pig Farming \\
\hline BANOTIFOP-COOP & $\begin{array}{l}\text { Bakossi National Park \& Bayang } \\
\text { Mbo Wildlife Sanctuary }\end{array}$ & $\begin{array}{l}\text { snails, bee keeping, bush mango, njansang, bitter } \\
\text { cola production. }\end{array}$ & $\begin{array}{l}\text { bush mango, njansang, } \\
\text { bitter cola }\end{array}$ \\
\hline
\end{tabular}

Source: Field Investigation (2017).

In our bid to advocate for a shift in approach of the WWF green business initiative, we propose that issues of diversification, technical and institutional capacity building, value chain development, and clarity in benefit sharing, among others should be captured effectively with set targets to be achieved by WWF and partners for improved outcomes. Such an approach should be in line with the aspirations of local populations around protected areas on the one hand, and the need for a conservation cooperative alliance on the other hand. Perhaps, it is necessary at this juncture to mention the views of the Global Environment Facility (GEF) which contents that to succeed, conservation initiatives need to be more than just financial mechanisms (GEF, 1999). The measures when applied will help to build a constituency for the environment, ultimately resulting in the allocation of more domestic resources for environmental conservation and protection. As the pressure on protected areas continue to rise amidst rising poverty levels, loss of livelihoods and significant outmigration, global efforts through "green economy" models have become fashionable in restoring conservation sites and livelihoods. This study contributes to the "green economy" discourse in the conservation-development sphere (UNEP, 2014).

\section{Acknowledgements}

We deeply acknowledge the participants from the target cooperatives who willingly accepted to provide the necessary data for the study. We equally thank the anonymous reviewers whose comments enriched the paper.

\section{Funding}

This study was generously funded by the Excellence Initiative Grant of the Technische Universitat Dresden (Grant ID: F-003631-553-U1G11170701).

\section{Notes}

Note 1. An earlier version of this paper was presented at the 4th FLARE Annual Conference, University of Copenhagen, 17-20 October 2018 (http://www.forestlivelihoods.org/annual-meeting-2018/)

The terms "green business model", "green enterprise", "green business initiative" and "green business approach" are used interchangeably to denote the livelihood support activities provided by WWF to partner conservation cooperatives in Cameroon.

Note 2. See Law No 94/01 of 20th January 1994 to regulate wildlife, forest resources and fisheries and Decree No 95 of 466 PM of 20th July 1995 to establish conditions of wildlife regulations. Also in 1996, the National Environment Management Plan (NEMP) was created which was aimed at conserving more resources in the country by increasing the amount of protected areas from 20 to $30 \%$ so that all the major biomes in the country could be represented. 
Note 3. The Likert scale (Likert 1932) can be applied in the assessment of community attitudes in natural resource management, protected and other conservation areas (Baral and Heinen 2007; Rodela and Udovc 2008; Pipinos and Fokiali 2009; Nicholas and Thapa 2010; Chowdhury \& Koike 2014).

\section{References}

Adams, W. M. (2001). Green development: environment and sustainability in the south. London: Routledge.

Adams, W., \& Mortimore, M. (1997). Agricultural intensification and flexibility in the Nigerian Sahel. Geographical Journal, 163(2), 150-160.

Adato, M., \& Meinzen-Dick, R. (2002) Assessing the Impact of Agricultural Research on Poverty Using the Sustainable Livelihoods Framework. FCND Discussion Paper 128, EPTD Discussion Paper 89, International Food Policy Research Institute, Washington DC.

AfDB/WWF (2012). Africa Ecological Footprint Report - Green Infrastructure for Africa's Ecological Security. African Development Bank and WWF - the World Wide Fund for Nature, Tunisia/Switzerland.

African Union Commission (AUC). (2015). Agenda 2063: The Africa We Want: First Ten-year Implementation Plan 2013-2023. Addis Ababa, Ethiopia: The African Union

Altenburg, T. (2006). The Rise of Value Chain Governance and Its Implications for UNIDO's Development Policy. presentation on behalf of the German Development Institute, Bonn, 2006.

Andersson K.P. (2013). Local Governance of Forests and the Role of External Organizations: Some Ties Matter More Than Others. World Dev, 43, 226-237.

Ashley, C., Mdoe, N., \& Reynolds, L. (2002). Rethinking wildlife for livelihoods and diversification in rural Tanzania: a case study from northern Selous. LADDER Working Paper No.15 March 2002. Retrieved from https://www.odi.org/sites/odi.org.uk/files/odi-assets/publications-opinion-files/3814.pdf

Baral, N., \& Heinen, J. T. (2007). Resource use, conservation attitudes, management intervention and park-people relations in the Western Terai landscape of Nepal. Environ. Conserv., 34(1), 1-9

Berkes, F. (2004b). Rethinking community-based conservation. Conservation Biology, 18(3), 621-30.

Berkes, F., Colding, J., \& Folke, C. (2003). Navigating social-ecological systems: building resilience for complexity and change. Cambridge: Cambridge University Press.

Blaikie, P., \& Jeanrenaud, S. (1997). Biodiversity and Human Welfare'. In K. B. Ghimire \& M. P. Pimbert (Eds.), Social change and Conservation: Environmental Politics and Impacts of National Parks and Protected Areas. London: Earthscan Publications Limited.

Bratton, M. (1994). Civil Society and Political Transition in Africa. Boston, MA: Institute for Development Research. Retrieved from https://www.issuelab.org/resources/19673/19673.pdf

Breitmeier, H., \& Volker, R. (2000). Environmental NGOs in an Emerging Global Civil Society. In The Global Environment in the Twenty-First Century: Prospects for International Cooperation, edited by Pamela Chasek. Tokyo, Japan: United Nations University. Retrieved from http://www.ciaonet.org/ book/chasek/

Brown, K. (2002). Innovations for conservation and development, Geographical Journal, 168(1), 6-17.

Brown, K. (2003b). Three challenges for a real people-centred conservation, Global Ecology and Biogeography, 12(2), 89-92.

Buchenrieder, G., \& Balgah, R.A. (2013). Sustaining livelihoods around community forests. What is the potential contribution of wildlife domestication? The Journal of Modern African Studies, 51(1), 57-84

Campese, J. (2012). Equitable Benefit Sharing: Exploring Experiences and Lessons for REDD+ in Tanzania. Report prepared with TNRF, AWF, CARE Tanzania, JGI, MCDI, MJUMITA, TFCG, TaTEDO, WCS, and WCST. Retrieved from http://www.tfcg.org/pdf/TZ\%20REDD\%20Equitable\%20Benefit $\% 20$ Sharing\%20 Experiences\%202012.pdf

Chambers, R. \& Conway, G. (1992). Sustainable rural livelihoods: practical concepts for the 21st Century. IDS Discussion paper No. 296, Brighton: IDS.

Charnovitz, S. (1997). Two Centuries of Participation: NGOs and International Governance. Michigan Journal of International Law, 18(2),183-286. 
Chowdhury, M.S.H., \& Koike, M. (2014). Conceptual Framework, Research Methods and Approaches. In M. S. H. Chowdhury (Ed.), Forest Conservation in Protected Areas of Bangladesh, World Forests 20. https://doi.org/10.1016/10.1007/978-3-319-08147-2_2, Springer International Publishing Switzerland 2014

Congo Basin Forest Partnership, CBFP. (2005). The Forests of the Congo Basin: A Preliminary Assessment. Retrieved from http://carpe.umd.edu/Documents/2005/focb_aprelimassess_en.pdf Accessed on 15/09/2016.

Cooka, N. J., Wright, G. D., \& Andersson, K. P. (2017). Local Politics of Forest Governance: Why NGO Support Can Reduce Local Government Responsiveness. World Development, 92(1), $203-214$. https://doi.org/10.1016/j.worlddev.2016.12.005 accessed 15.06.2018.

Dalal-Clayton, B. Dent, D., \& Dubois, O. (2003). Rural planning in Developing Countries: Supporting Natural Resource Management and Sustainable Livelihoods. Earthscan Publishing Ltd, London.

De Haan, L. J. (2000). Globalization, Localization and Sustainable Livelihood. Sociologia Ruralis, 40(3), 339-365.

Dercon, S., \& Krishnan, P. (1996). Income portfolios in rural Ethiopia and Tanzania: choices and constraints. Journal of Development Studies, 32(6), 850-875.

DFID. (1999). Sustainable Livelihoods guidance sheets. UK: Department for International Development. Retrieved

from http://files.ennonline.net/attachments/871/dfid-sustainable-livelihoods-guidance-sheet-section1.pdf

Ellis, F. (1996). Policy implications of rural livelihood diversification. mimeo, Overseas Development Group, University of East Anglia, Norwich.

Fiallo, E., and Jacobson, S. (1995). Local Communities and protected areas. Attitudes of rural residents towards conservation and Machalilla National Park, Ecuador. Environmental Conservation, 22(3), 241-249.

Folke, C., Hahn, T., Olsson, P. \& Norberg, J. (2005). Adaptive governance of social-ecological systems, Annual review of Environment and Resources, 30(1), 441-73.

Gibson, C. C. (1999). Politicians and Poachers: The Political Economy of Wildlife Policy in Africa. Cambridge: Cambridge University Press.

Gibson, C.C., Andersson K.P., Ostrom E., \& Shivakumar, S. (2005). The Samaritan's Dilemma: The Political Economy of Development Aid. New York: Oxford University Press.

Global Environment Facility (GEF). (January 1999, February 1999, April 1999). GEF Lessons Notes.

Gratwicke, B., Seidensticker, J., Shrestha, M., Vermilye, K. \& Birnbaum, M. (2007). Evaluating the performance of a decade of Save The tiger Fund's investments to save the world's last wild tigers. Environmental Conservation, 34, 255-265.

Hoermann, B., Choudhary, D., Choudhury, D., \& Kollmair, M. (2010). Integrated Value Chain Development as a Tool for Poverty Alleviation in Rural Mountain Areas. An analytical and strategic framework. International Centre for Integrated Mountain Development, Kathmandu, June 2010. Retrieved from http://lib.icimod.org/record/8058/files/attachment_703.pdf

Hou, X. (2013). Background Paper for REDD+ Benefit Sharing Dialogue. The Forests Dialogue, Washington, D.C., U.S., March 2013.

Howe, C. (2009). The Role of Education as a Tool for Environmental Conservation and Sustainable Development. A dissertation submitted for the degree of Doctor of Philosophy at Imperial College London July 2009 Retrieved from https://www.iccs.org.uk/wp-content/thesis/phd-howe,caroline09.pdf accessed 21.11.2017.

Jepson, P., \& Canney, S. (2003). State of wild Asian elephant conservation 2003. Conservation Direct, 47.

Kellert, S.R. (1996). The value of life. Island Press, Washington, D.C., 263 pp.

Kimengsi, J.N. \& Balgah, R.A (2017). Repositioning Local Institutions in Natural Resource Management: Perspectives from Sub-Saharan Africa. Schmollers Jahrbuch, 137, 115 - 138. Duncker \& Humblot, Berlin.

King, B. (2007). Conservation and community in the new South Africa: a case study of the Mahushe Shongwe Game Reserve. Geoforum, 38, 207-219.

King, B. (2009). Conservation Geographies in Sub-Saharan Africa: The Politics of National Parks, Community Conservation and Peace Parks. Geography Compass, 3(2009), 1-14. 
Lambi, C. M., Kimengsi, J.N., Kometa, C.G., \& Tata, E.S (2012). The Management of Protected Areas and the Sustenance of Local Livelihoods in Cameroon. Environment and Natural Resources Research (ENRR), 2(3), 10-18.

Likert, R. (1932). A technique for the measurement of attitudes. Arch Psychol, 14(1), 11-55

Lindhjem, H., Aronsen, I., Bråten, K. G., \& Gleinsvik, A. (2010). Experiences with benefit sharing: issues and options for REDD-plus. Econ Pöyry, Oslo.

McNeely, J., \& Miller, K. (1984). National parks, conservation and development, the role of protected areas in sustaining society. Washington, DC: Smithsonian Institution Press.

Mercer, C. (2002). NGOs, civil society and democratization: a critical review of the literature. Prog Dev Stud, 2, $5-22$.

Muchapondwa, E., \& Stage, J. (2015). Whereto with institutions and governance challenges in African wildlife conservation? Environ. Res. Lett., 10.

Muller, E., \& Johnson, S. (2009). Forest Governance and Climate-Change Mitigation. A Policy Brief Prepared by ITTO and FAO Published by FAO and ITTO, 2009.

Mustalahti, I., \& Lund, J. F. (2010). Where and How Can Participatory Forest Management Succeed? Learning From Tanzania, Mozambique, and Laos, Society \& Natural Resources, 23(1), 31-44.

Mustalahti, I., \& Nathan, I. (2009). Constructing and sustaining Participatory Forest Management: lessons from Tanzania, Mozambique, Laos and Vietnam. Folia Forestalia Polonica, series A, 2009, 51(1), 66-76.

Nelson, F., \& Agrawal, A. (2008). Patronage or participation? Community-based natural resource management reform in Sub-Saharan Africa Dev. Change, 39, 557-85

Neumann, R. P. (1997). Primitive Ideas: Protected Area Buffer Zones and the Politics of Land in Africa. Development and Change, 28, 559-582.

Newmark, W. D. (2008). Isolation of African Protected Areas. Front Ecol Environ, 6(6), 321-328.

Nicholas, L., \& Thapa, B. (2010) Visitor perspectives on sustainable tourism development in the Pitons Management Area World Heritage Site, St. Lucia. Environ Dev Sustain, 12(5), 839-857.

Njiforti, H. L., \& Tchamba, M. N. (1993). Conflict in Cameroon: Parks for or Against People? In E. Kemf (Ed.), The Law of the Mother: Protecting Indigenous Peoples in Protected Areas (pp. 173-178). Sierra Club Books, San Francisco.

OECD. (2011). Towards Green Growth. Organisation for Economic Co-operation and Development (OECD). Paris, France.

Ostrom, E. (1995). Designing complexity to govern complexity ed S Hanna and M Munasinghe Property Rights and the Environment: Social and Ecological Issues. Washington, DC: World Bank.

Ostrom, E., Schroeder, L., \& Wynne, S. (1993). Institutional Incentives and Sustainable Development: Infrastructure Policies in Perspective. Westview Press, Boulder, CO.

Peskett, L. (2011a). Benefit sharing in REDD+: Exploring the implications for poor and vulnerable people. World Bank/REDDnet. Retrieved from http://redd-net.org/resource-library/Benefit+sharing+in+REDD $\% 2 \mathrm{~B} \% 3 \mathrm{~A}+$ Exploring+the+implications + for + poo...

Pham, T.T., Brockhaus, M., Wong, G., Dung, L.N., Tjajadi, J.S., Loft, L., Luttrell C., \& Assembe Mvondo, S. (2013). Approaches to benefit sharing: A preliminary comparative analysis of 13 REDD+ countries. Working Paper 108. CIFOR, Bogor, Indonesia.

Pipinos, G., \& Fokiali, P. (2009). An assessment of the attitude of the inhabitants of Northern Karpathos, Greece: towards a framework for ecotourism development in environmentally sensitive areas. Environ Dev Sustain, 11(3), 655-675.

Pretzsch, J. (2005). Forest related rural livelihood strategies in national and global development. Paper presented at The International Conference on Rural Livelihoods, Forests and Biodiversity, 19-23 May 2003, Bonn, Germany, http://citeseerx.ist.psu.edu/viewdoc/download? doi=10.1.1.465 .1581\& rep = rep1\&type=pdf accessed 20.11.2017.

Rodela, R., \& Udovc, A. (2008). Participation in nature protection: does it benefit the local community? a Triglav National Park case study. Int J Biodiv Sci Manage, 4, 209-218. 
Saini, S., Thapliyal, P., Kilakkencherry K.V., Sharma, D., Sinha, G., \& Mehra, S. (2016). NTFPS value chain Development for rural communities of Madhya Pradesh, India- A case study of chakoda (Cassia Tora L.). International Journal of Managing Value and Supply Chains (IJMVSC), 7(3). http://dx.doi.org/10.5121/ ijmvsc.2016.7302 19

Salafsky, N., \& Wollenberg, E. (2000). Linking Livelihoods and Conservation: A Conceptual Framework and Scale for Assessing the Integration of Human Needs and Biodiversity. World Development, 28(8), 1421-1438, 2000

Scherl, L.M., \& O'Keeffe, A.J. (2016). Capacity Development for Protected and Other Conserved Areas in the Pacific Islands Region: Strategy and Action Framework 2015-2020. Gland, Switzerland: IUCN. 42pp. DOI: http://dx.doi.org/10.2305/IUCN.CH.2016.BIOP AM A.2.en

Scoones, I. (1998). Sustainable Rural Livelihoods. A framework for Analysis. IDS Working Paper No. 72. Institute of Development Studies.

Sesabo, J. K., Lang, H., \& Tol, R. S. J. (2006). Perceived Attitude and Marine Protected Areas (MPAs) establishment: Why households' characteristics matters in Coastal resources conservation initiatives in Tanzania. Working Paper FNU-99.

Shukla, S. (2004). Strengthening Community-based Conservation through Traditional Ecological Knowledge. In Introduction to International Indigenous Knowledge. The Pennsylvania State University, University Park.

Singh, N. (1996). Community Adaptation and Sustainable Livelihoods: Basic Issues and Principles. IISD, Canada.

Sperling, F, Granoff, I., \& Vyas, Y. (2012). Facilitating Green Growth in Africa: Perspectives from the African Development Bank. Discussion Paper. African Development Bank

Springer, J. (2013). Taking a Livelihoods, People-Centered Approach to Conservation. Ecosystem Degradation and Livelihoods: Working with the Communities most at Risk. Retrieved from https:/c402277.ssl.cf1.rackcdn.com/publications/1/files/original/WWFBinaryitem24462.pdf?1342687910

Tchindjang, M., \& Fogwe, Z. N. (2009). Ecotourism in Protected Areas of Cameroon: Trends, Problems and Prospects. In C. M. Lambi (Ed.), Cameroon: A Country at Crisis Crossroads: An Anthology in the Social Sciences. Nab Ventures, Bamenda, Cameroon. pp. 197-221.

Tiffen, M., Mortimore, M., \& Gichuki, F. (1994). More People, Less Erosion: Environmental Recovery in Kenya. Chichester, England: John Wiley and Sons.

Torres, A. B., \& Skutsch, M. (2014). Challenges for pro-poor benefit sharing schemes in the implementation of REDD+ in Mexico. Technical Series: Forest Governance and Economics, No. 2. San Jose, Costa Rica: IUCN, pp. 51.

UNEP. (2011). Towards a Green Economy: Pathways to Sustainable Development and Poverty Eradication. UN DESA/Population Division, 2012. World Urbanization Prospects: The 2011 Revision, Highlights.

UNEP. (2014). Using Models for Green Economy Policymaking. United Nations Environment Programme, 2014. $\mathrm{http}: / / w w w . u n-p a g e . o r g / f i l e s / p u b l i c / c o n t e n t-p a g e /$ unep_models_ge_f or_web.pdf accessed 17.11.2017.

United Nations Conference on Sustainable Development (UNCSD). (2012). The Future We Want. Outcome Document.

United Nations Industrial Development Organization, UNIDO. (2009). Agro-value chain analysis and development. The UNIDO Approach A staff working paper. United Nations Industrial Development Organization, Vienna.

UN-REDD Programme. (2011). UN-REDD Programme social and environmental principles and criteria. Version 3-draft for consultation. September 2011. The United Nations Collaborative Programme on Reducing Emissions from Deforestation and Forest Degradation in Developing Countries. Retrieved from http://www.un-redd.org/Multiple_Benefits_SEPC/ tabid/54130/Default.aspx

Wells, M., \& Brandon, K. (1992). People and parks: linking protected area management with local communities. Washington, DC: The World Bank

Western, D., \& Wright, R. M. (1994). Natural connections: perspectives in community-based conservation. Washington DC: Island Press.

World Bank. (2012). Inclusive Green Growth: The Pathway to Sustainable Development. The World Bank Group. Washington, D.C. 
Wright, G., \& Andersson, K. (2012) Non-Governmental Organizations, Rural Communities and Forests: A Comparative Analysis of Community-NGO Interactions. Small-scale For, 12(1), 33-50. Retrieved from http://link.springer.com/10.1007/s11842-012-9206-2

WWF SAWA Updates. (2016). Supporting Conservation, Improving Local Livelihood: Strengthening Civil Society organizations. WWF-CFP, March 2016.

WWF. (2015). Engaging the Stewards of Nature Partnering with Indigenous Peoples and Local Communities. Retrieved from https://c402277.ssl.cfl.rackcdn.com/publications/368/files/original/Engaging the_Stewards_of_Nature_Partnering_with_Indigenous_Peoples_and_Local_Communities.pdf?1345737030

WWF. (2017). Conserving Wildlife and Enabling Communities in Namibia. Retrieved from https:/www.worldwildlife.org/projects/conserving-wildlife-and-enabling-communities-in-namibia

\section{Copyrights}

Copyright for this article is retained by the author(s), with first publication rights granted to the journal.

This is an open-access article distributed under the terms and conditions of the Creative Commons Attribution license (http://creativecommons.org/licenses/by/4.0/). 